\title{
Las ruinas que habito
}

\section{Erika Kuhn}
- as imágenes de Juan Manuel Martínez Jaramillo caminan desde donde na- cen, es decir, conservan el registro de su origen: la memoria convertida en ruina.

Si algo caracteriza a las ruinas, según Judy Wajcman, es que hacen objeto de los restos de un objeto, así, cada imagen que presenta aquí Juan Manuel es, en cierto modo la presencia de lo ausente, la estrategia que ha tenido a bien construir para garantizar que algo ocurrió, incluso antes de que se formase el recuerdo de ello, porque igual, quizá, nunca tuvo lugar, así que en sus imágenes no encontrarán una temática, sino la incertidumbre misma desde donde fueron creadas, el ajuste fallido entre la impronta y la ausencia como marca distintiva de su memoria.

Su propuesta artística se podría poner en términos de algo que, original y estructuralmente en falta, insiste en su hacer. Embarcaciones, naufragios, faros, ruinas de casas a cuestas como si fuera una arquitectura interna en la que cohabita con sus reminiscencias, son tan sólo algunos de los vestigios que Juan Manuel nos muestra de su andar sobre sus propios pasos para reencontrarse en su propio extravío, memoria de lo que se olvidó, ilegible, pero ahú, en algín lado, insistente.

Por lo tanto, presenciar Las ruinas que habito no rememora nada ni a nadie, no habla de un suceso pasado, es acontecimiento para nuestra mirada, aquí y ahora, donde espectador, obra y artista participan de éste, transformándose uno a través del otro. 


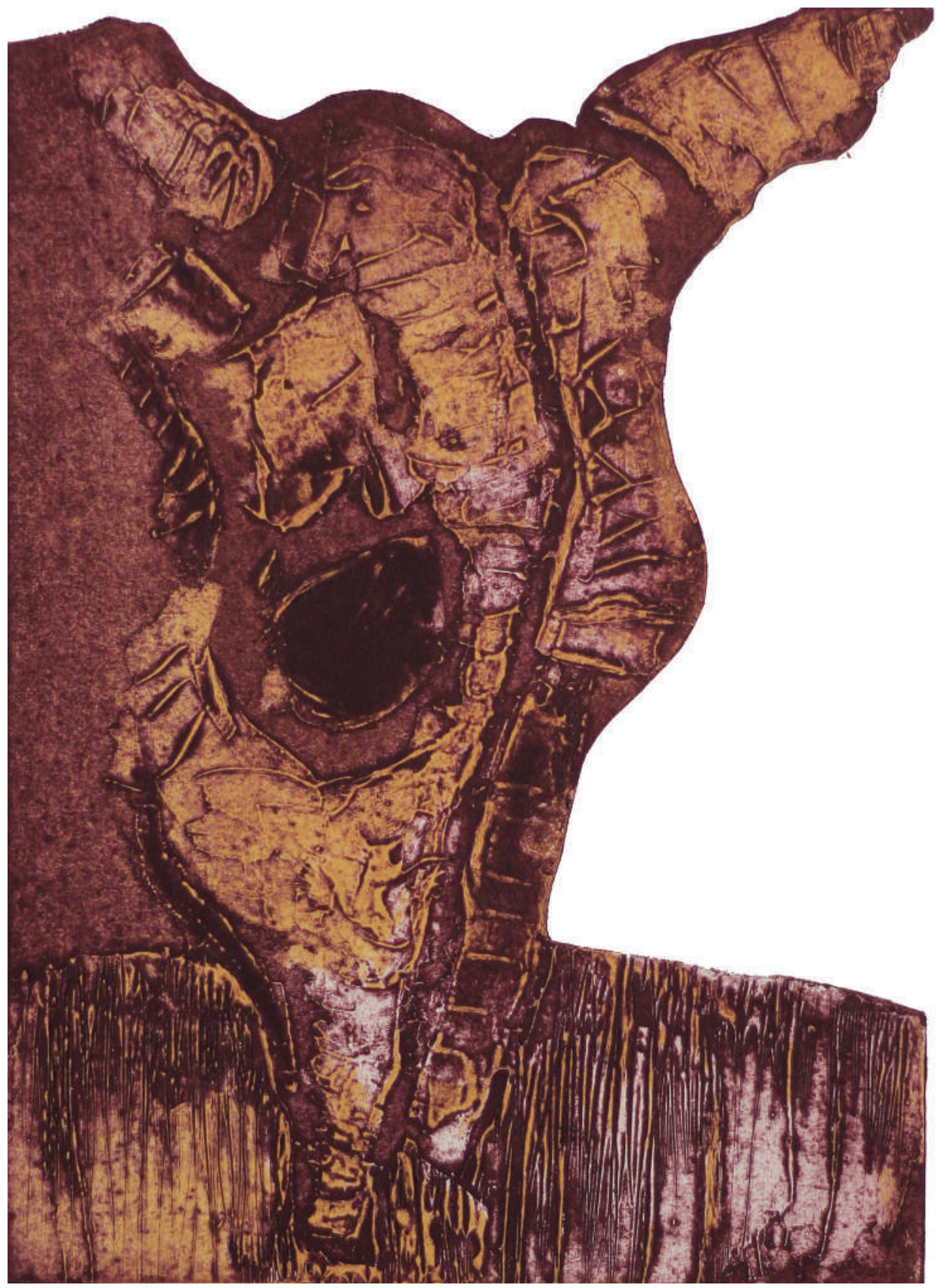

Incertidumbre y muerte. (2018). Colografía: Juan Manuel Martínez Jaramillo. Prohibida su reproducción en obras derivadas. 


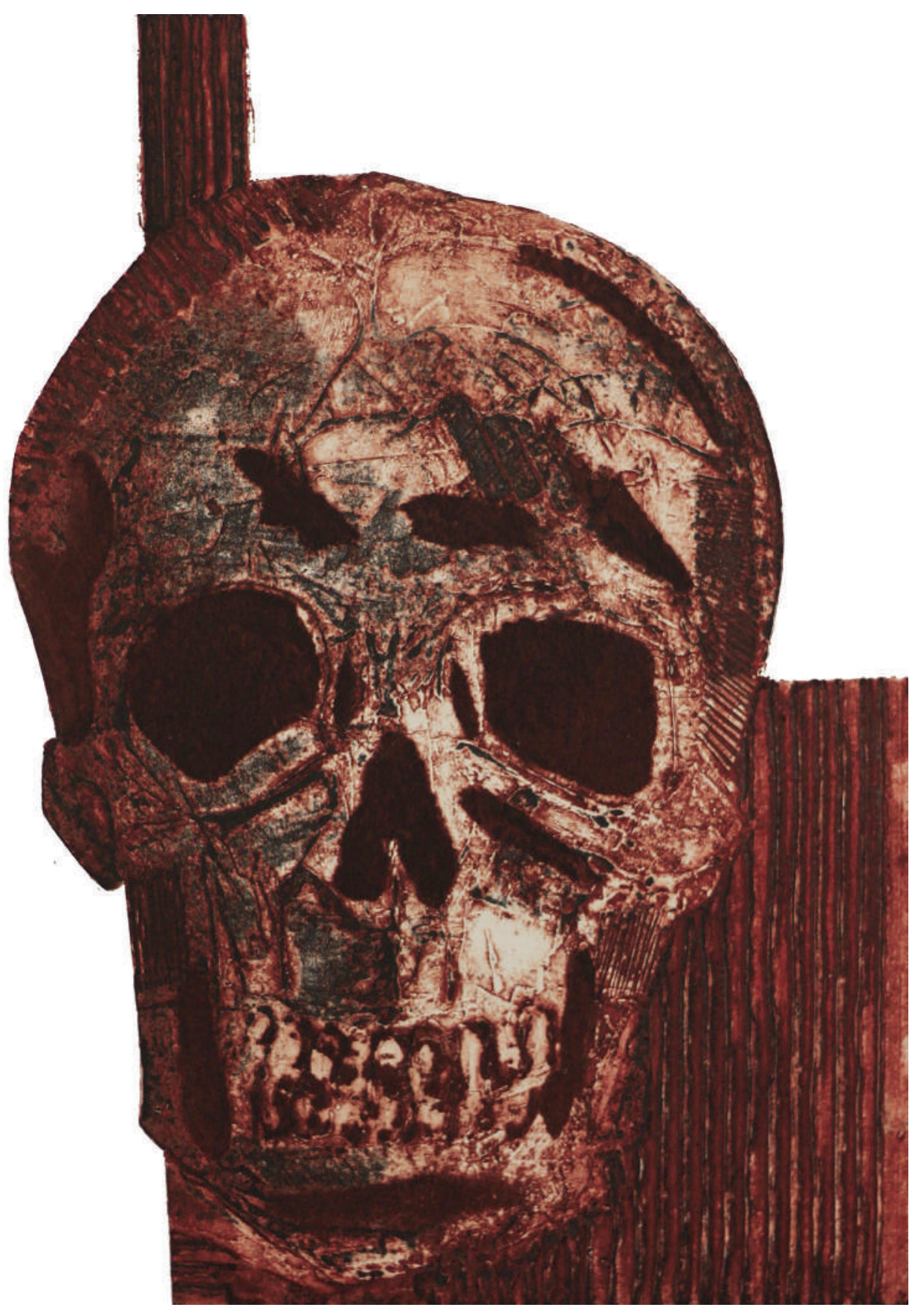

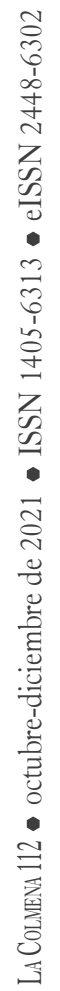

Suerte rima con muerte (2018). Colografía: Juan Manuel Martínez Jaramillo. Prohibida su reproducción en obras derivadas. 


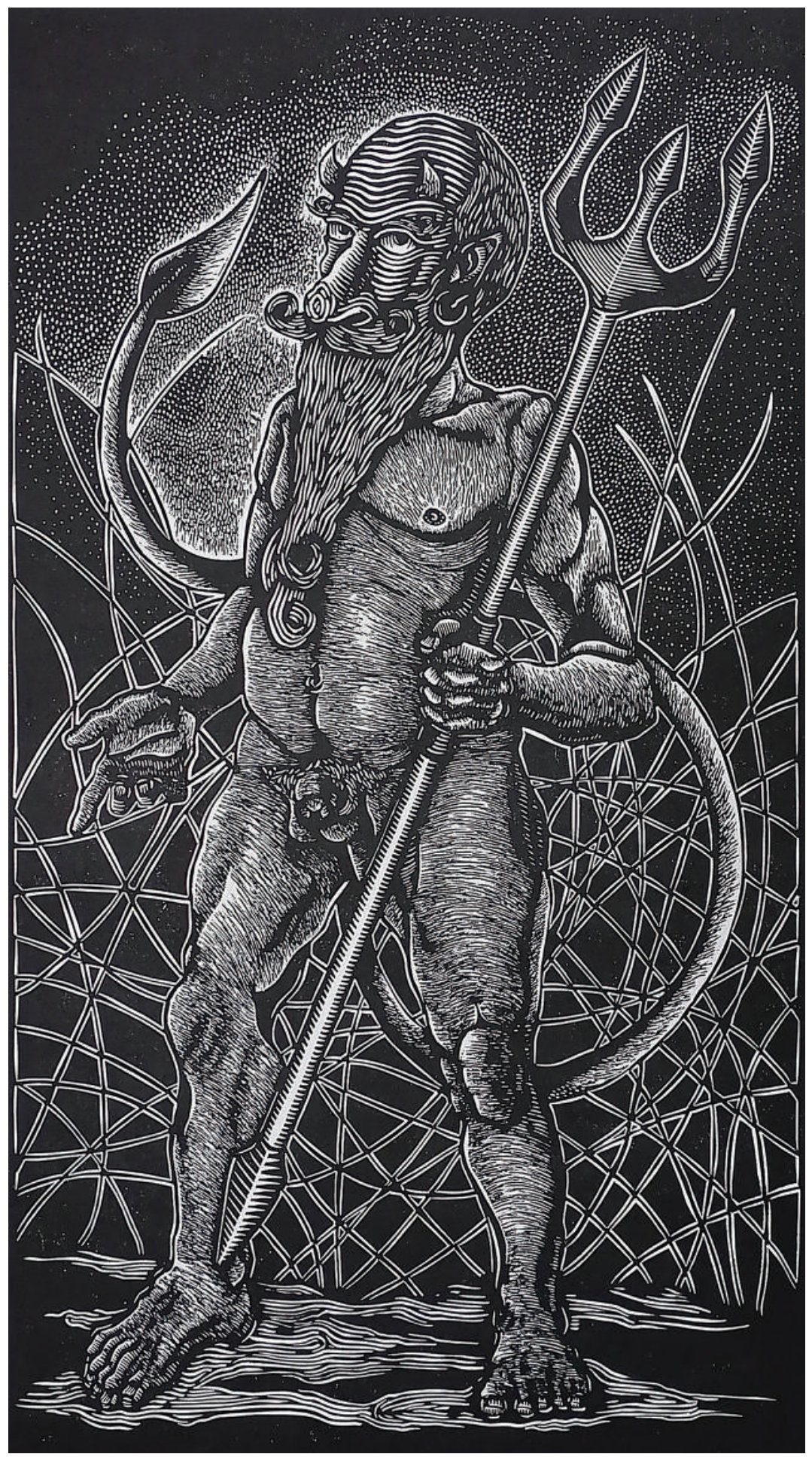

El amigo (2020). Grabado en MDF: Juan Manuel Martínez Jaramillo. Prohibida su reproducción en obras derivadas. 


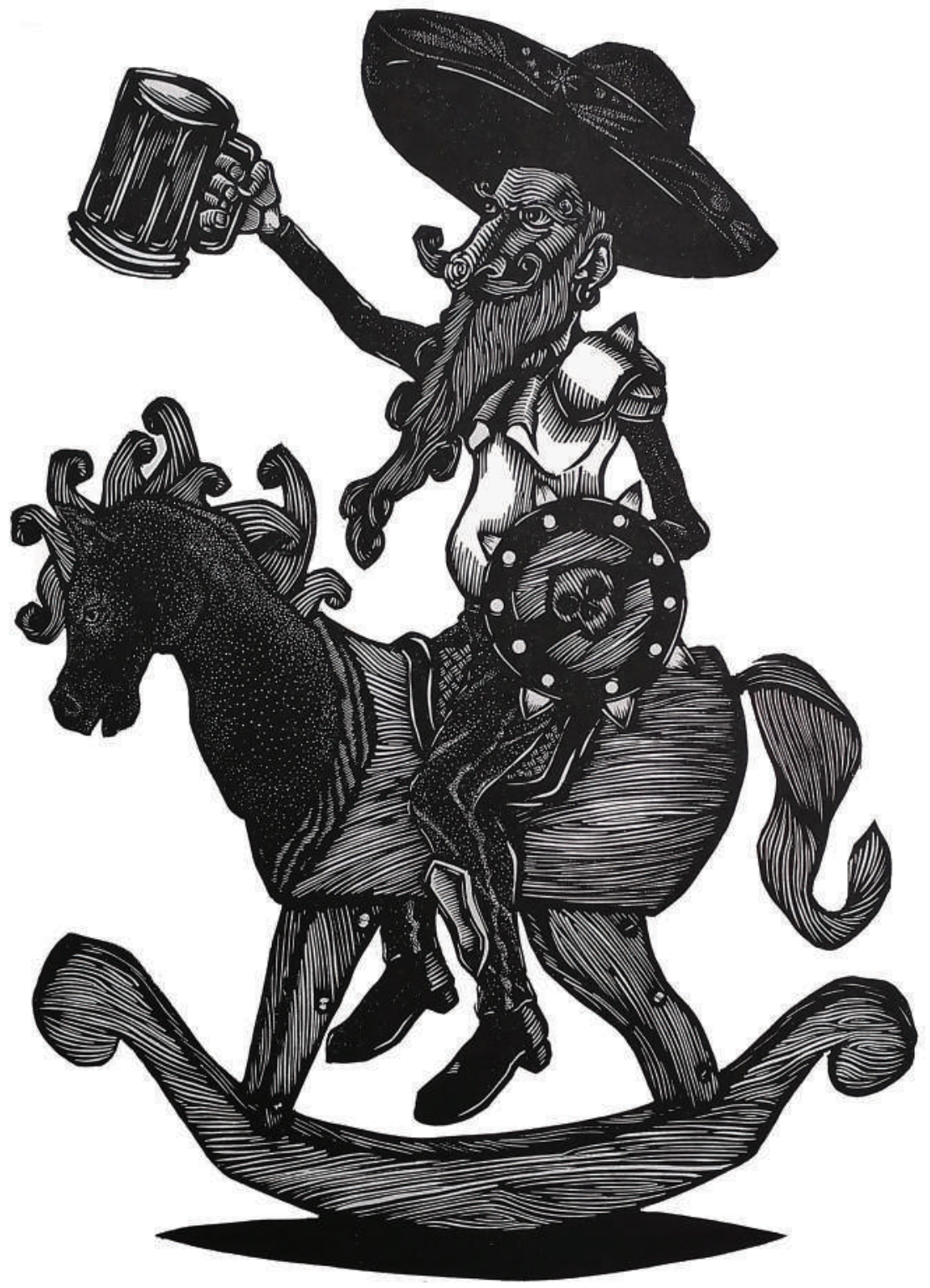

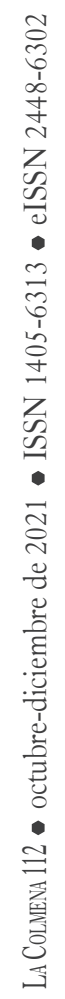

Soñador y Quijote (2020), Grabado en MDF: Juan Manuel Martínez Jaramillo. Prohibida su reproducción en obras derivadas. 


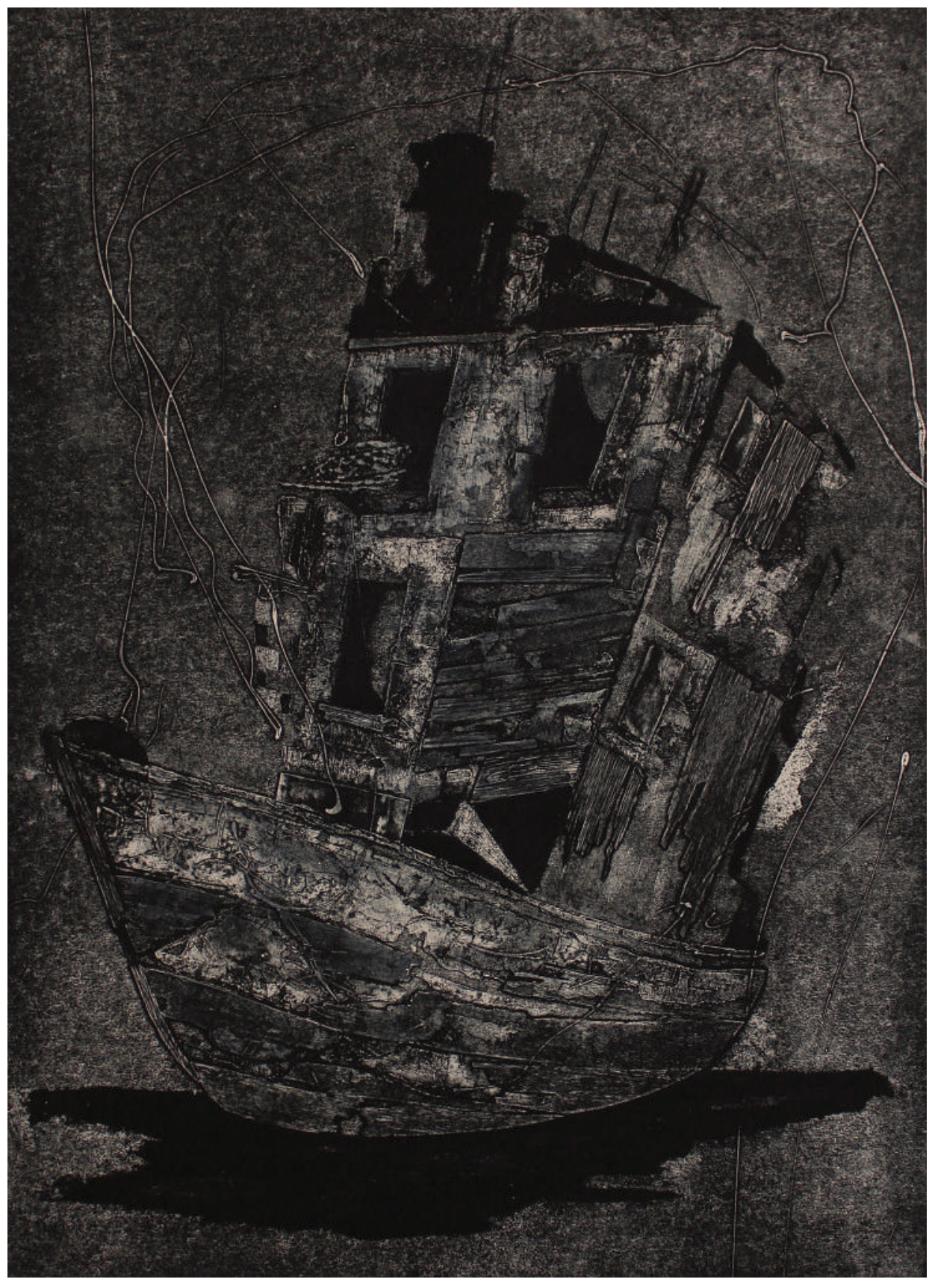

Corazón errante ( de la serie de los naufragios y reconstrucciones) (2020). Colografía: Juan Manuel Martínez Jaramillo.

Prohibida su reproducción en obras derivadas. 


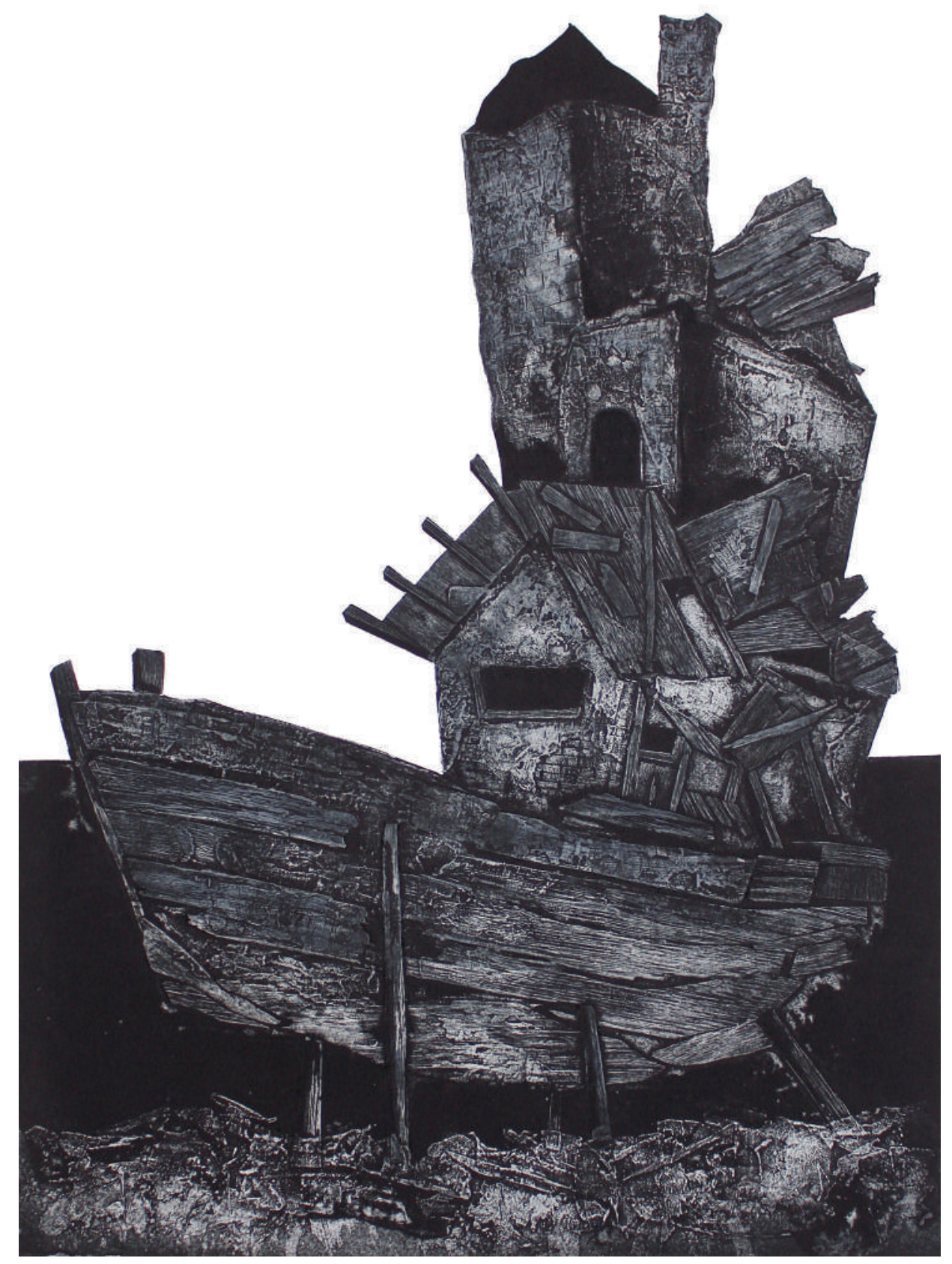

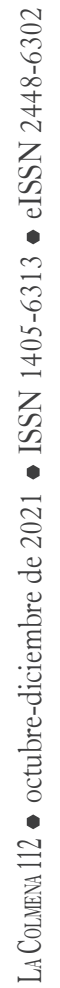

Apego (2019). Colografía: Juan Manuel Martínez Jaramillo. Prohibida su reproducción en obras derivadas. 


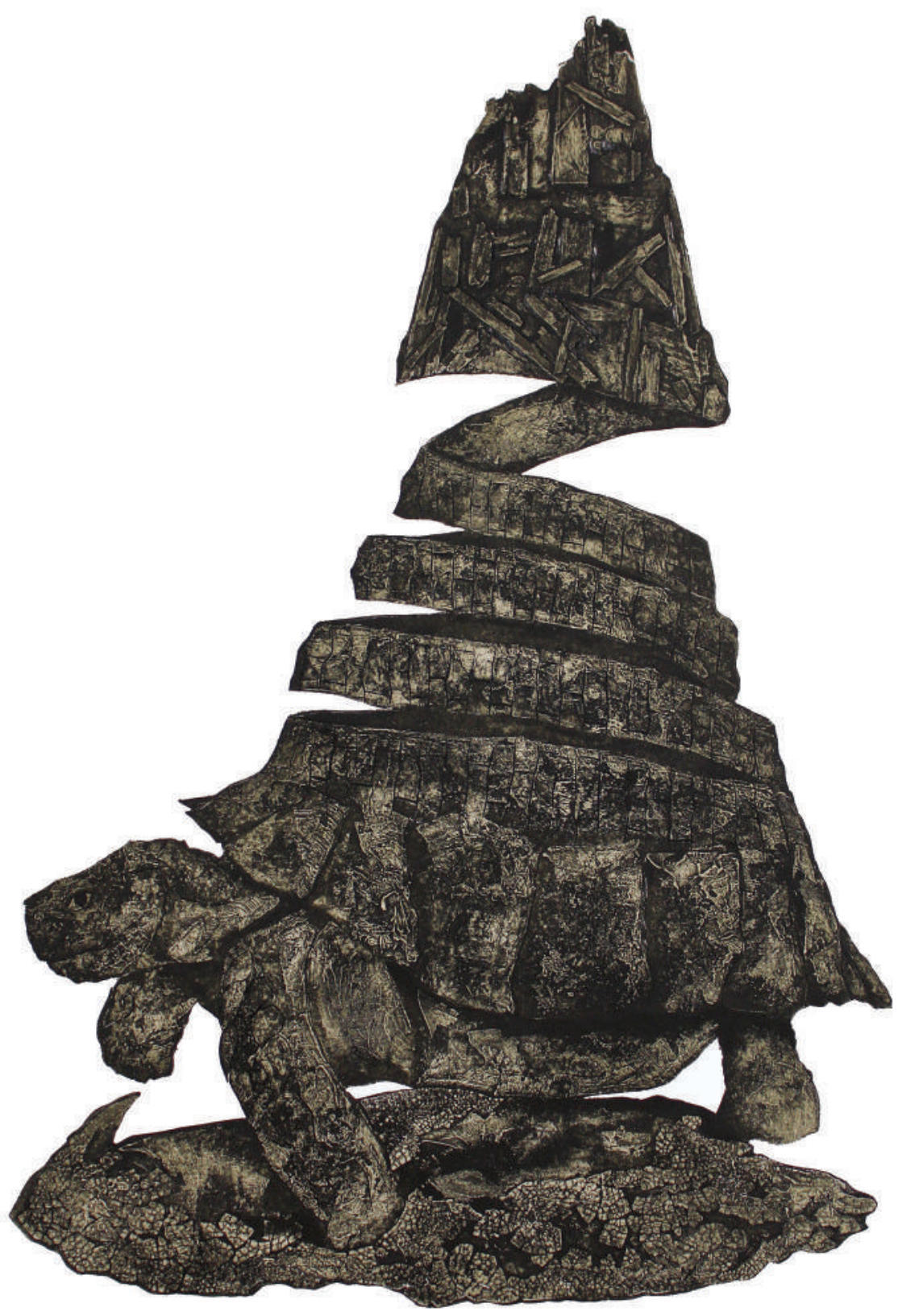

Las ruinas que habito (2021). Colografía: Juan Manuel Martínez Jaramillo. Prohibida su reproducción en obras derivadas. 


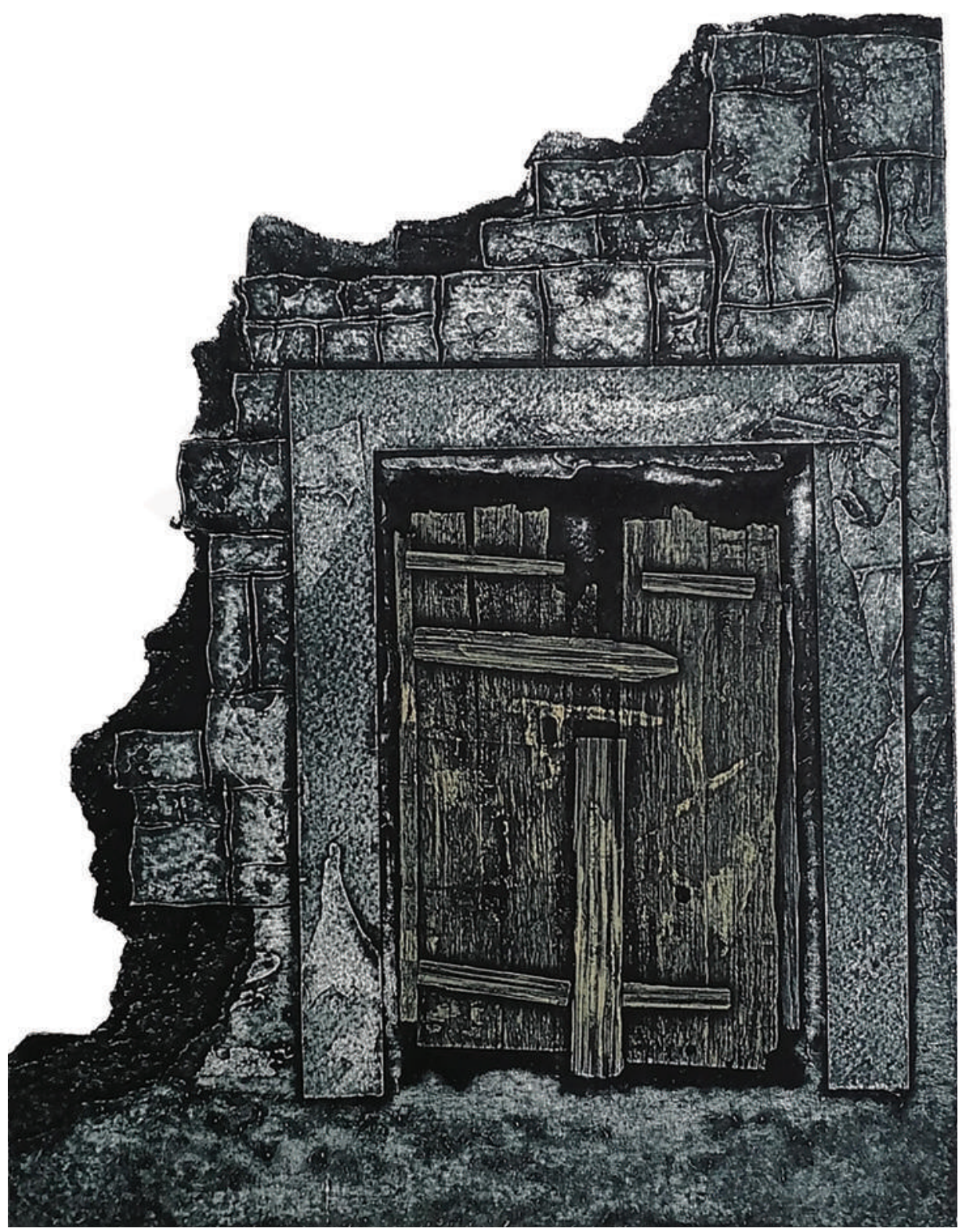

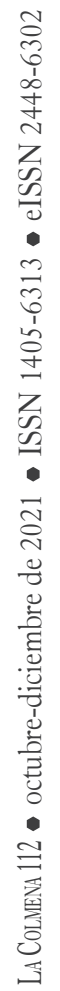

Memorias (2020). Colografía: Juan Manuel Martínez Jaramillo.

Prohibida su reproducción en obras derivadas. 


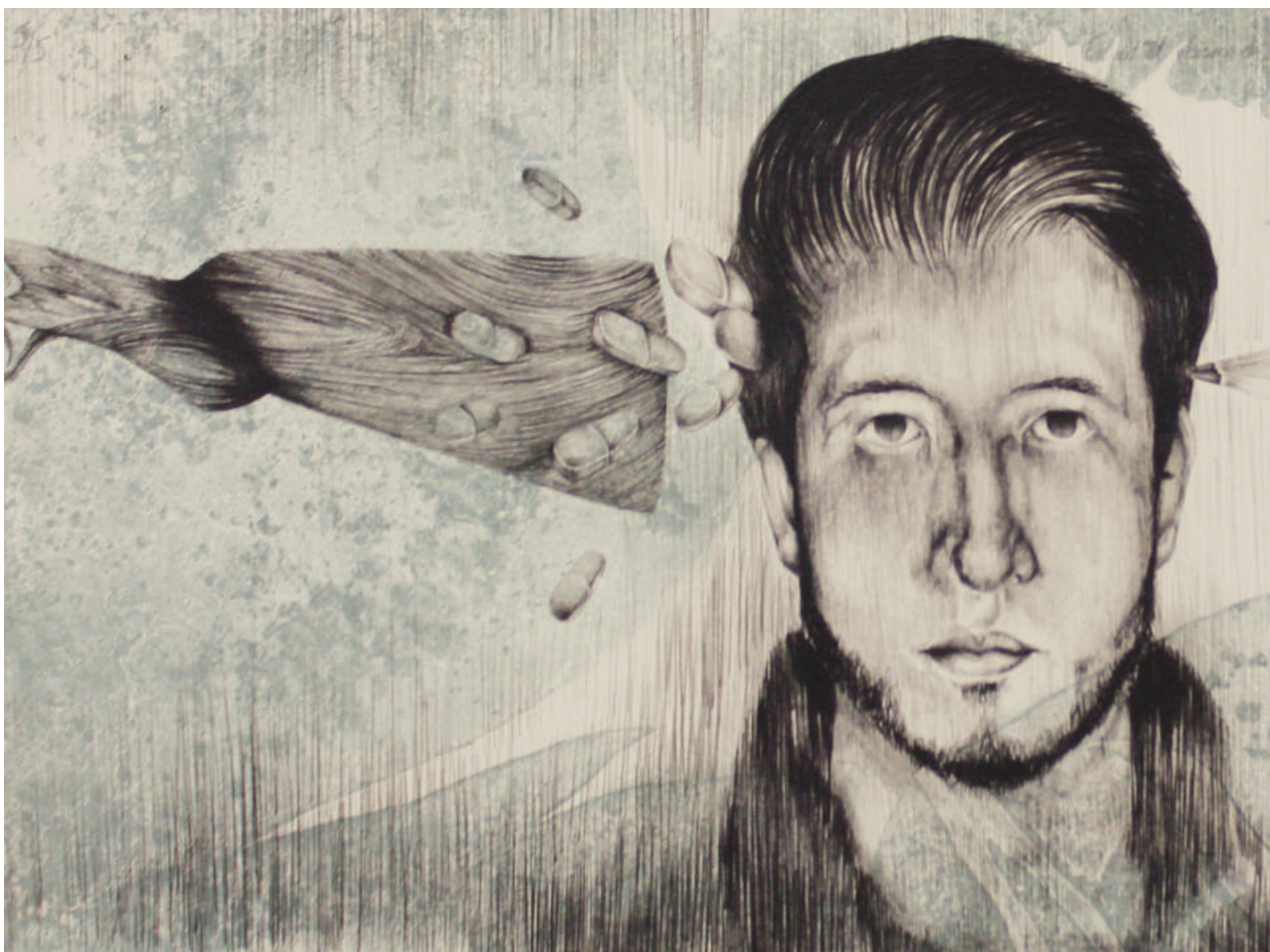

En el abismo de mis pensamientos, la muerte se disfraza de medicina (2018). Litografia en seco: Juan Manuel Martínez Jaramillo.

Prohibida su reproducción en obras derivadas.

Juan Manuel Martínez Jaramillo. Licenciado en Artes Plásticas por la Escuela de Bellas Artes de Toluca (EBAT), México, con especialidad en Gráfica. Ha participado en las exposiciones colectivas: International Ex Libris Exhibition Skopje (Skopje Macedonia); Imagen Lírica (Estado de México, 2016); Sensaciones y Sentimientos (Estado de México, 2016); Calaca Tilica y Flaca (Estado de México, 2016); Aberraciones (Estado de México, 2017); Alfeñique (Estado de México, 2018); En nuestro Tiempo (Guanajuato, 2018); Los Colores de la Muerte (Coahuila, 2019); Las Intermitencias de la Muerte (Coahuila, 2019); High Graphics 2020 (Tatarstan, Rusia) Reminiscencias (Estado de México, 2021); Holguín, Relieve de una Vida (Estado de México, 2021). Recientemente, presentó su primera exposición individual Las Ruinas que Habito en el C. C. U. Casa de las Diligencias, Toluca, Estado de México.

Fue seleccionado en la Sexta Bienal Nacional de Artes Gráficas Shinzaburo Takeda (2019) y en la XII Bienal Nacional de Pintura y Grabado Alfredo Zalce (2020). Ganador de una beca completa para hacer una residencia en La Ceiba Gráfica en Veracruz (2019). 


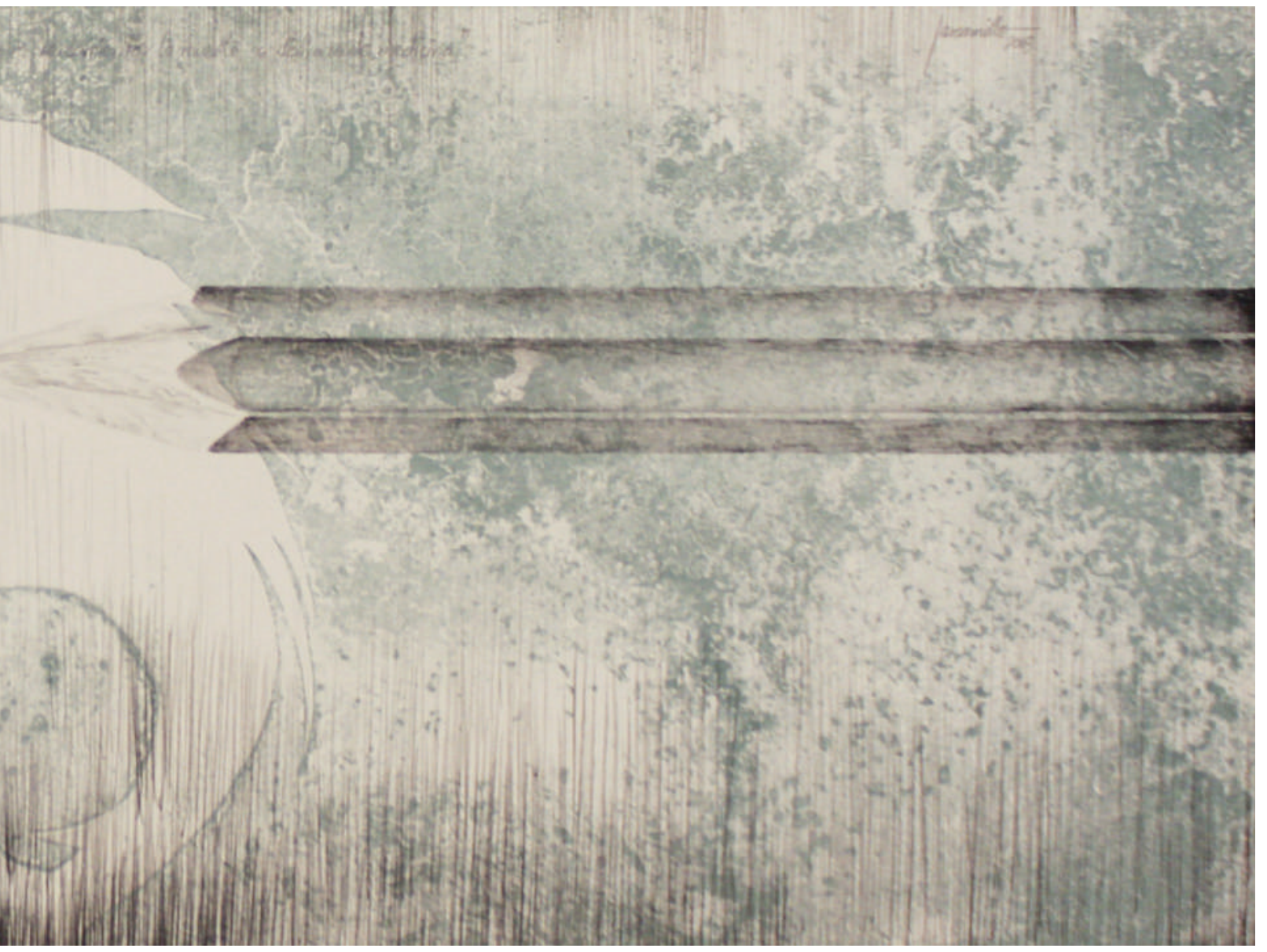

Erika Valeria Kuhn Orozco. Es originaria de Toluca, Estado de México. Recibió Mención Honorífica en la Escuela de San Carlos. Imparte el Seminario de Tesis en la Licenciatura en Artes Plásticas de la EBAT. Igualmente, es asesora en el Departamento de Exámenes Profesionales en el Área de Artes Plásticas.

Recibido: 9 de julio de 2021

Aprobado: 3 de noviembre de 2021 